\title{
Analisis dan Evaluasi Penerapan Sistem Informasi Smart Library Amikom Resource Centre Dengan Metode Pieces Framework
}

\author{
Dwiyantoro \\ PT Chevron Pacific Indonesia, BP- E-Procurement System Team \\ JL. Rumbai KM 25, Lembah Damai-Rumbai-Pekanbaru \\ E-Mail: Dwiyantoro66@gmail.com
}

\begin{abstract}
Information system is one part the rapid development of information, the system used has advantages and disadvantages that need to be done an update so that the system can work effectively. For that we need an analysis of the effectiveness and efficiency of a system. One method that can be used in analyzing systems is Pieces Fremwork where there are 6 indicators related to performance, information, control, efficiency, service. Much research is related to system evaluation, but the evaluation of the Smart Library system owned by Amicome has not been done. This research uses a quantitative descriptive, with data collection techniques using questionnaires and observations. Data analysis the mean formula and uses interval scale. The results of the study stated that of the six domains of the Pices method said to be good with an average mean value of performance (4.4), information (4.3), Economist (3.9), control / scuritu (5.0), efficiency (4.55), service (4.43). Based on the research conducted it can be concluded that the application of the smart library system in the Amikom resource center was declared good when viewed from the PIECES Analysis and was quite effective and efficient in its use.
\end{abstract}

Keywords: Information Systems; Library; Pieces Framework

\begin{abstract}
ABSTRAK
Sistem Informasi merupakan salah satu dari bagian perkembangan informasi yang begitu pesat, tentunya sistem yang digunakan memiliki kelebihan dan kelemahan yang perlu dilakukan sebuah pembaharuan agar sistem dapat bekerja secara efektif dan efisien. Untuk itu perlu adanya analisis tentang tingkat efektifitas dan efisiensi suatu sistem. Salah satu metode yang dapat digunakan dalam menganalisis sistem adalah Pieces Fremwork dimana terdapat 6 indikator yang terkait tentang performance, information, control/scuritu, efisiency, service. Banyak penelitian yang berkaitan dengan evaluasi sistem, akan tetapi evaluasi sistem Smart Library yg di miliki oleh
\end{abstract}

Tik Ilmeu : Jurnal Ilmu Perpustakaan dan Informasi IAIN Curup | p-issn: 2580-3654; e-issn:2580-3662 
Amicome belum banyak dilakukan. Penelitian ini menggunakan pendekatan deskriptif kuantitatif, dengan teknik pengumpulan data menggunakan kuesioner dan observasi. Analisis data menggunakan rumus mean dan menggunakan skala interval. Hasil dari penelitian menyatakan bahwa dari ke enam domain metode Pices Framework dikatakan baik dengan nilai rata-rata mean yaitu performance $(4,4)$, information (4,3), Economis (3,9), control/scuritu (5.0), efisiency $(4,55)$, service $(4,43)$. Berdasarkan penelitian yang dilakukan maka dapat disimpulkan bahwa penerapan sistem smart library yang ada di Amikom resource center dinyatakan sudah baik jika dilihat dari Analisis PIECES dan sudah cukup efektif dan efisien dalam penggunaannya.

Kata Kunci : Sistem Informasi; Perpustakaan; Pieces Framework

\section{A. PENDAHULUAN}

Dengan perkembangan teknologi yang semakin pesat memberikan dampak positif baik perseorangan maupun lembaga, pasalnya teknologi saat ini sudah menjadi penopang dalam berjalan nya suatu lembaga ke arah yang lebih baik, salah satu dampak positif perkembangan teknologi yaitu kemudahan dalam mengakses informasi. Pemanfaatan sistem informasi ini banyak digunakan oleh orgaisasi/ lembaga baik pemerintahan maupun swasta, bersifat profit atau pun non profit, tidak heran jika saat ini sistem informasi sudah di gunakan di mana-mana seperti jasa penyedia informasi perpustakaan yang saat ini juga sudah mulai berbenah diri untuk mengikuti perkembangan zaman dengan kemudahan-kemudahan yang ditawaran seperti kebutuhan administrasi, pelayanan, pengelolaan data, dan kebutuhan lainnya yang berkaitan dengan informasi perpustakaan.

Supriyanto, (2009) menyatakan bahwa teknologi informasi banyak digunakan untuk pengelolaan pekerjaan karena daya efektivitas dan efisiensi yang telah terbukti mampu mempercepat kinerja. Namun sistem informasi tidak terlepas dari perawatan yang berkelanjutan guna meng up date sistem untuk pembaharuhan atau penambahan fitur.Supriyatna, (2015) mendefinisikan sistem informasi sebaga kumpulan komponen yang saling berhubungan, mengumpulkan atau mendapatkan, memproses, menyimpan dan mendistribusikan informasi guna menunjang pengambilan keputusan dalam sebuah organisasi atau perusaha. Selain itu Wahyono, (2005) menyatakan bahwa sistem informasi merupakan suatu cara tertentu untuk menyediakan informasi yang dibutuhkan oleh organisasi untuk beroprasi dengan cara yang sukses dan untuk organisais bisnis dengan cara yang menguntungkan. 
Dari keterangan tersebut makan dapat dikatakan bahwa sistem informasi merupakan suatu cara yang dapat dilakukan untuk meyediakan informasi secara mudah dengan mengabungkan komponen-komponen secara terintegrasi antara komponen manual dan komponen terkomputerisasi, dengan tujuan untuk mengumpulakn data serta mempermudah pemakai mendapatkan informasi hal ini tentunya akan mempermudah dalam pengelolaan perpustakaan.

Salah satu perpustakaan yang menggunakan sistem informasi yaitu Amikom Resource Centre dengan nama smart library yang di kembangkan oleh lembaga induknya sendiri. dengan adanya smart library ini tentunya banyak sekali kemudahan-kemudahan yang di tawarkan mulai dari kemudahan administrasi, layanan, pengolahan dan lain-lain, hal tersebut akan membuat pustakawan memberikan pelayanan yang lebih cepat dan mudah bagi pemustaka. Untuk mengetahui apakah sistem ini efektif atau tidak dalam penerapannya, perlu adanya analisis dan evaluasi tentang smart library yang di gunakan di amikom resource centre, evaluasi dapat dilakukan dengan menggunakan pendekatan metode analisis pieces, Menurut A. R. Dewi \& Nurjamiyah (2018) analisis picess merupakan metode yang digunakan untuk memperoleh pokok-pokok yang lebih spesifik. Sedangkan menurut Fatah, (2008) Analisis pieces merupakan metode yang digunkan untuk mengidentifikasi masalah yang terjadi, dengan melakukan analisis masalah terhadap kinerja sistem informasi, ekonomi, keamanan aplikasi, efisiensi, dan pelayanan pelangan. Whitten \& Dkk, (2005) mengatakan metode ini terdiri dari enam kategori diantaranya yaitu performance, information, control/scuritu, efisiency, service. Sistem informasi yang digunakan haruslah memiliki performance yang baik, informasi yang disediakan oleh sistem harus akurat, kontrol yang ada tidak mudah di masuki oleh pihak yang tidak memiliki hak akses, efisiensi yang di tawarkan pada sistem harus baik, serta service yang ada pada sistem informasi harus fleksibel.

Dari beberapa pendapat di atas maka dapat dijelaskan bahwa terdapat beberapa sumber mengenai metode analisis pices diantaranya yang dikemukakan oleh Dewi \& Nurjamiyah, (2018), Supriyatna, (2015),Diana \& Andhyka, (2018), Whitten \& Dkk, (2005) mengatakan bahwa metode Picess Framework ini terdiri dari enam kategori diantaranya yaitu performance, information, control/scuritu, efisiency, service.

Dengan melakukan pendekatan menggunakan metode analisis pices diharapkan dapat memberikan penilaian secara menyeluruh tentang penerapan sistem yang digunakan, dan hasil yang didapatkan dari analisi ini 
diharapkan dapat menjadi acuan untuk terus mengembangkan sistem untuk kemajuan yang lebih baik lagi. Ada beberapa penelitian sejenis mengenai analisis pieces diantaranya yaitu penelitian yang dilakukan oleh Nani Agustina, (2018) yang berjudul evaluasi penggunaan sistem informasi ERP dengan metode pieces framework, penelitian yang dilakukan oleh Agus Suharto, (2018) dengan judul analisa evaluasi sistem informasi manajemen administrasi akademik dengan metode analisis pieces studi kasus pada STMIK ERESHA, dan penelitian yang dilakukan oleh R. S. Dewi, Marchada Rizky, \& Rifai, (2016) dengan judul analisa pieces penerapan digital monitoring informasi penyewaan ruko pasar 8 pada PT. Alam sutera realty, tbk.

Berdasarkan latar belakang di atas maka dapa disimpulkan bahwa rumusan masalah dalam penelitian ini yaitu "Analisis Dan Evaluasi Sistem Informasi Smart Library Amikom Resource Centre Dengan Menggunakan Pendekatan Metode Pieces Framework".

\section{Metode Penelitian}

Jenis penelitian dalam makalah ini yaitu penelitian deskriptif kuantitatif Menurut Arikunto \& Suharsimi,(2014) penelitian ini bertujuan untuk memecahkan masalah penelitian dengan memaparkan keadaan objek yang di selidiki baik seseorang, lembaga, pabrik, dll.

1. Pemilihan sampel

a. Populasi

Sugiyono, (2018) menyatakan bahwa populasi merupakan wilayah generalisasi yang terdiri atas objek/subjek yang mempunyai kualitas dan karakteristik tertentu yang ditetapkan oleh peneliti untuk dipelajari dan kemudian ditarik kesimpulannya.

Populasi dalam penelitian ini yaitu staf perpustakaan yang menggunakan sistem informasi, jumlah staf yang mengunakan sistem informasi berjumlah 12 orang staf perpustakaan

b. Sampel

Teknik pengambilan sampel dalam penelitian ini menggunakan purposive sampling dimana teknik pengambilan sampel sumber data dengan pertimbangan tertentu. Sampel di pilih karena berkaitan dengan bidang pekerjaan yang berhubungan langsung dengan sistem informasi yang digunakan yaitu smart library.

2. Metode Pengumpulan data

a. Observasi 
Metode Observasi/pengamatan adalah cara pengumpulan data dengan terjun dan melihat langsung ke lapangan terhadap objek yang diteliti. Dalam Metode observasi yang akan dilakukan oleh peneliti yaitu mengamati langsung serta mencatat secara sistematis tentang aplikasi smart library yang digunakan, mulai dari conten-conten yang ada sampai melihat prosedur-prosedur pengunaannya.

b. Kuesioner

Metode selanjutnya yaitu Kuesioner yang merupakan teknik pengumpulan data yang dilakukan dengan cara memberi seperangkat pertanyan/ pernyataan tertulis kepada responden untuk di jawabnya. Kuesioner akan disebarkan ke staf perpustakaan yang menangani/langsung menggunakan aplikasi smart library pada aktifitas sehari-hari diperpustakaan mulai dari penolahan, layanan sirkulasi, opac dll. Dengan jenis angket yang digunakan yaitu angket tertutup dimana jawaban sudah disediakan dan responden tinggal memilih jawabannya.

c. Wawancara dilakuakn untuk mengumpulkan data tentang kelebihan yang d tawarkan oleh sistem dalam hal ini peneliti melakukan wawancara kepada salah satu pengguna sistem Smart Library.

3. Pengukuran data

Dalam penelitian ini pengukuran data yang dilakukan dengan menggunakan skala likert's (Dermawan, 2013) menyatakan skala likert's digunakan untuk mengukur sikap, pendapat, dan persepsi seseorang tentang fenomena social. Sekala likert's yang digunakan dari skala 1-5 dengan pernyataan sebagai berikut :

$\begin{array}{ll}\text { Sangat Setuju } & : 5 \\ \text { Setuju } & : 4 \\ \text { Ragu-Ragu } & : 3 \\ \text { Tidak Setuju } & : 2 \\ \text { Sangat Tidak Setuju } & : 1\end{array}$

4. Uji Validitas dan Reliabilitas

a. Uji Validitas

Dalam penelitian ini uji validitas menggunakan rumus $\mathrm{df}=$ n- 2 dengan signifikasi $10 \%$. Responden /data dalam penelitian ini berjumlah 12. Sehingga untuk mendapatkan hasil sesuai dengan rumus $\mathrm{df}=12-2=10$ jadi df yaitu 10 dengan begitu dapat disimpulkan bahwa nilai $r$ tabel adalah 0,497 
114 | Dwiyantoro: Analisis dan Evaluasi Penerapan...

Berdasarkan uji validitas yang dilakukan di dapatkan hasil sebagai berikut:

Tabel 1 Uji Validitas

\begin{tabular}{cccc}
\hline Butir Pernyataan & r tabel & r hitung & Validitas \\
\hline P1 & 0.497 & 0,793 & Valid \\
P2 & 0.497 & 0,725 & Valid \\
P3 & 0.497 & 0,586 & Valid \\
P4 & 0.497 & 0,723 & Valid \\
P5 & 0.497 & 0,520 & Valid \\
P6 & 0.497 & 0,584 & Valid \\
P7 & 0.497 & 0,532 & Valid \\
P8 & 0.497 & 0,582 & Valid \\
P9 & 0.497 & 0,530 & Valid \\
P10 & 0.497 & 0,499 & Valid \\
P11 & 0.497 & 0,621 & Valid \\
P12 & 0.497 & 0,627 & Valid \\
P13 & 0.497 & 0,511 & Valid \\
P14 & 0.497 & 0,523 & Valid \\
P15 & 0.497 & 0,503 & Valid \\
P16 & 0.497 & 0,798 & Valid \\
\hline
\end{tabular}

Sumber Data : diolah tahun 2018

Berdasarkan keterangan di atas dapat disimpulkan bahwa data kuesioner valid dilihat dari nilai $r$ hitung lebih tinggi dari pada $r$ tabel

b. Uji Reliabilitas

Dalam menguji reliabilitas angket di katakan reliabel jika cronbach's Alpha lebih besar di bandingkan $r$ tabel. Hasil uji reliabilitas menggunakan SPSS 24 yang dilakukan menunjukan bahwa nilai cronbach's alpha yaitu 0,660 itu artinya nilai tersebut lebih besar dibandingkan dengan $r$ tabel jadi dapat disimpulkan bahwa angket reliabel.

5. Analisis Data 
Untuk menganalisis data, metode yang digunakan yaitu dengan menentukan nilai rata-rata dari nilai kuesioner. Setelah mendapatkan jawaban dari masing-masing responden langkah selanjutnya kemudian ditabulasikan dan dihitung nilai rata-rata (mean)-nya pada setiap indikator yang sudah ditetapkan, adapun rumus mean dapat dilihat pada keterangan di bawah ini:

$$
\begin{aligned}
& \mathrm{Me}=\frac{\sum X_{i}}{N} \\
& \text { Keterangan: } \\
& \mathrm{Me}=\text { Mean atau rata-rata } \\
& \sum \mathrm{x}_{\mathrm{i}}=\text { Jumlah nilai } \mathrm{x} \text { ke I sampai ke } \mathrm{n} \\
& \mathrm{N}=\text { Jumlah individu }
\end{aligned}
$$

Untuk mendapatkan data dari hasil perhitungan rata-rata tentang penerapan system informasi smart library Amikom Resource Centre dengan menggunakan skala interval. Untuk mendapatkan skala interval tersebut terlebih dahulu dicari skala (RS) menggunakan rumus yang dikemukakan oleh (Bilson, 2008) sebagai berikut

$$
R s=\frac{m-n}{b}
$$

Keterangan

$\mathrm{RS}=$ rentang skala yang dicari

$\mathrm{m}$ = angka tertinggi dalam mengukur kuesioner yang digunakan dalam penelitian. Skor antara 1-5. Dapat disimpulkan bahwa angka tertinggi adalah 5, dan angka terendah adalah 1 .

$\mathrm{n} \quad=$ angkat terendah dalam pengukuran yaitu 1

b = banyaknya pilihan yang tersedia yaitu 5

Jadi dapat disimpulkan bahwa skala (RS) dapat diketahui sebagai berikut :

$$
\begin{aligned}
R S & =\frac{5-1}{5} \\
R S & =0,8
\end{aligned}
$$

Rentang skala yang di dapatkan dari nilai interval sebnyak 0,8 adalah sebaga berikut :

Skala dan kategori penilaiaan

$4,2<\mathrm{X} \leq 5,0$ (Sangat Baik)

$3,4<\mathrm{X} \leq 4,2$ ( Baik) 


$$
\begin{aligned}
& 2,6<\mathrm{X} \leq 3,4 \text { (Cukup Baik) } \\
& 1,8<\mathrm{X} \leq 2,6 \text { (Buruk) } \\
& 1,0<\mathrm{X} \leq 1,8 \text { (Sangat Buruk) }
\end{aligned}
$$

\section{B. HASIL DAN PEMBAHASAN}

Perpustakaan amikom yogyakarta merupakan perpustaakaan yang berada di luar jurusan dan bertangung jawab langsung kepada pimpinan lembaga induknya. Perpustakaan ini termasuk ke dalam perpustakaan perguruan tinggi, perpustakaan ini didirikan beramaan dengan lembaga induknya yaitu Stimik Amikom dengan akta pendirian atas nama Daliso Rudianto, S.H No. 76 Tanggal 29 Desember 1992, berlokasi di JL Woler Monginsidi No.8 Yogyakarta. Kemudian pada tahun 2002 STIMIK AMIKOM akhirnya memiliki gedung sendiri yang berlokasi di Ring Road Utara Condong catur, dengan berpindahnya ke gedung baru perpustakaan juga mengikuti lembaga induknya dan menempati Gedung Unit II Kampus terpadu di JL. Ring Road Utara dan masih di bawah UPT (Unit Pelayanan Teknis.

\section{Analisis Sistem Informasi}

\section{a. Kelebihan Smart Library}

Smart Library merupakan aplikasi yang di kembangakan oleh lembaga induknya dan digunakan Amikom Resource Centre pada tahun 2007, sistem informasi ini merupakan perangkat lunak yang digunakan untuk laanan, sirkulasi, data master, pencarian buku. Dengan demikian aplikasi ini dapat mengumpulkan data serta informasi yang penting sehingga harus dijaga keamanannya. Namun sistem ini masih menggunakan localhost sehingga tidak dapat diakses melalui web, hanya komputer yang terinstal softwere smart library saja yang bisa menggunkan aplikasi ini. Untuk itu hal tersebut yang harus di kembangkan sehingga nantinya softwere ini bisa di akses melalui internet dan dapat diakses dimana saja.

Analisis yang dilakuakan pada sistem informasi di tinjau dari segi tampilan dan fitur-fitur yang ada pada smart library yang digunakan oleh Amikom Resource Centre diantaranya yaitu 


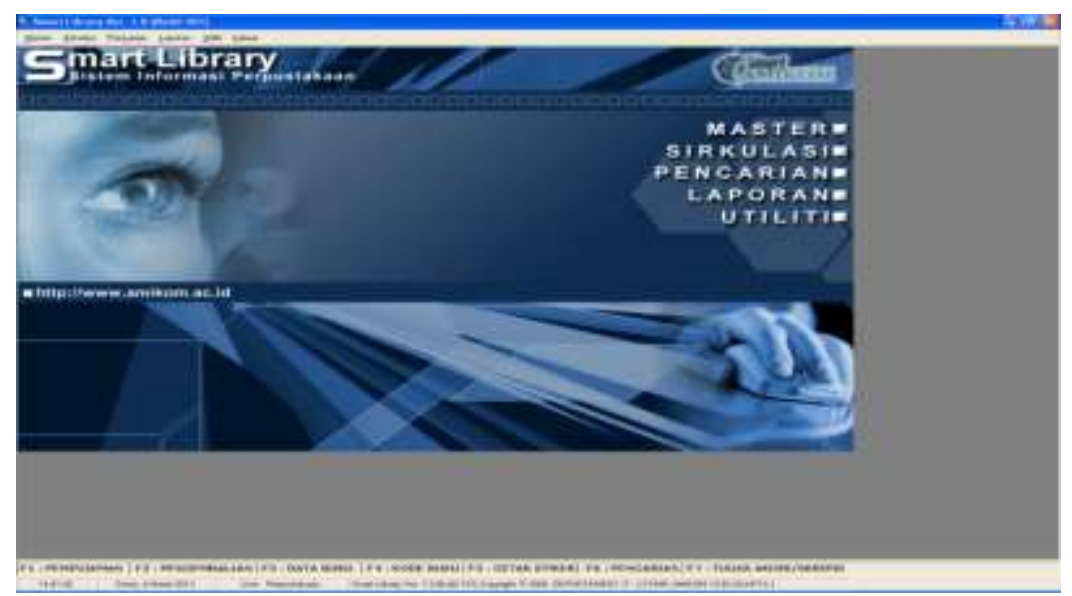

Gambar 1 Menu Utama Smart Library

Berdasarkan gambar di atas di jelaskan bahwa terdapat 6 item menu yang di gunakan dalam aplikasi Smart Library diantaranya yaitu master, sirkulasi, pencarian, laporan, utiliti, dan keluar. Dari ke 6 item menu piihan tersebut di bagi lagi menjadi beberapa bagian yang memiliki sub item di dalamnya.

Kemudahan yang di tawarkan pada sistem ini ialah pengguna sistem dapat menggunakan tombol bantuan tampa harus meng clik menu yang ada di bagian atas pengguna cukup menekan F1 pada kybord untuk membuka proses peminjaman, menekan F2 untuk pengembalian, F3 untuk data buku, F4 untuk kode buku, F5 untuk mencetak stiker/barkot, F6 untuk pencarian, dan F7 untuk tugas akhir/skripsi. Dari keterangan diatas tentunya di dukung dari pernyataan yang di kemukakan oleh pengguna Smart Library Itu sendiri yaitu bapak Arif yang menyatakan bahwa

"Smart Library ini cukup mudah dalam penggunaannya, selain dapat menggunakan menu pilihan kita juga bisa menggunakan keybord untuk mempercepat waktu pelayanan. Dengan katalain efisiensi waktu pelayanan dapat dilakuakn dengan cepat"

Keterangan tersebut tentunya di dukung oleh pernyataan yang di kemukakan oleh Supriyatna, (2015) Dimana Sistem memaksimalkan sumber yang tersedia termasuk orang, waktu, aliran form, serta meminimalkan penundaan proses. 
b. Kekurangan Sistem

Kekurangan pada sistem Smart Library dapat dilihat pada keterangan di bawah ini.

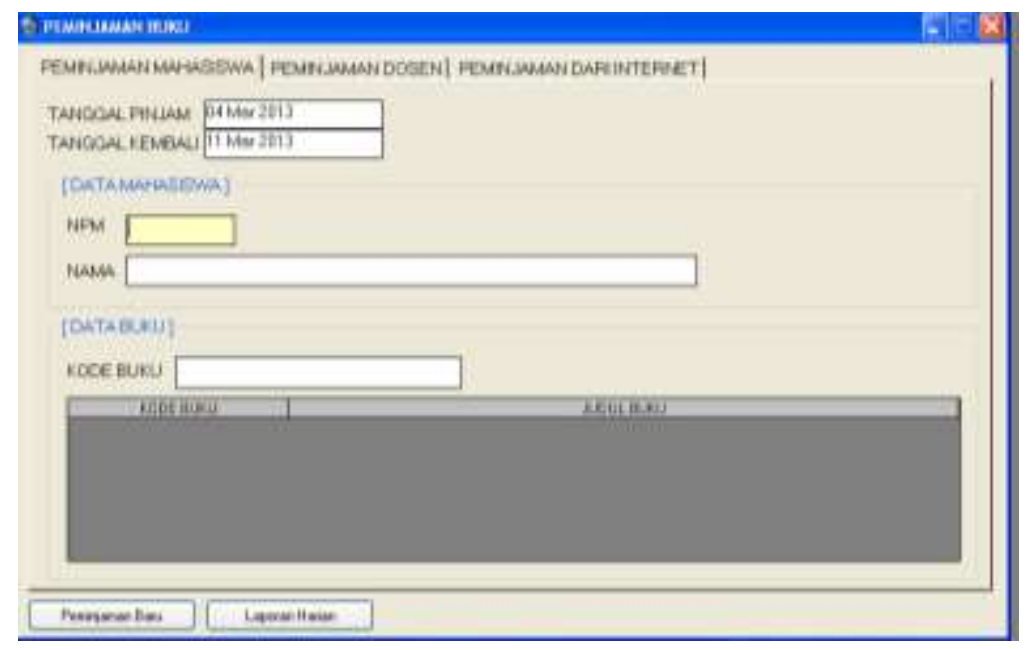

Gambar 2 Tampilan Layanan Sirkulasi

Berdasarkan keterangan di atas dapat dijelaskan bahwa untuk melakukan peminjaman pustakawan hanya mengimputkan NPM kemudian akan keluar nama peminjam, setelah itu petugas tinggal meng scan barkot yang ada pada buku yang ingin di pinjam. Pada bagian atas terdapat tanggal pinjam dan tanggal kapan pemustaka harus mengembalikan buku.

Namun layanan sirkulasi yang ada pada smart ibrary belum bisa dikatakan maksimal karena jika pemustaka meminjam 1 buku dan ke esokan harinya ingin meminjam 2 buku, pemustaka harus mengembalikan buku yang pertama di pinjam kemudian baru bisa meminjam ke 3 buku terseut berdasarkan keterangan tersebut tentu sistem informasi kurang efektif karena belum bisa memberikan layanan yang diinginkan dan andal pada siapa saja.

Keterangan di atas tentunya bertentangan dengan pernyataan yang dinyatakan oleh Whitten \& Dkk, (2005) yaitu sistem menyediakan layanan yang diiginkan dan andal pada siapa saja, dan bersifat flaksibel.

\section{Analisis data}

Berdasarkan hasil kuesioner yang disebarkan kepada 10 orang responden untuk meng evaluasi dan analisis penerapan sistem 
informasi smart library amikom dengan metode pieces, dengan melakukan penghitungan data mengunakan interval kelas dari masing-masing variabel berdasarkan metode Pieces Framework.

1. Hasil Dan Analisis domain Performance

Pada domain Peformance terdapat tiga pernyataan yang digunakan untuk menganalisis Performance pada sistem smart library. Hasil analisis dapat dilihat pada keterangan di bawah ini

Tabel 2 Nilai Total Skor Dari Domain Performance

\begin{tabular}{ccccc}
\hline $\begin{array}{c}\text { Butir } \\
\text { Pernyataan }\end{array}$ & Responden & $\begin{array}{c}\text { Jumlah } \\
\text { Skor }\end{array}$ & Mean & kategori \\
\hline PER-A & 10 & 41 & 4.1 & Baik \\
PER-B & 10 & 44 & 4.4 & Sangat Baik \\
PER-C & 10 & 47 & 4.7 & Sangat Baik \\
Total & $\mathbf{3 0}$ & $\mathbf{1 3 2}$ & $\mathbf{4 . 4}$ & Sangat Baik
\end{tabular}

Sumber Data : diolah tahun 2018

Berdasarkan analisis yang dilakukan pada sistem informasi dengan domain performance didapatkan hasil ratarata Mean 4,4 dengan kategori sangat baik, sehingga dapat disimpulkan bahwa peformance pada sistem informasi smart library dikatakan positif tentang kinerja sistem informasi smart library.

Hasil domain performance diatas sesuai dengan pernyataan yang di katakan oleh (Whitten \& Dkk, 2005) sistem harus menyediakan throughput dan waktu respons yang cukup.

2. Hasil Dan Analisis Domain Information

Pada domain Information terdapat empat pernyataan yang digunakan untuk menganalisis Information pada sistem smart library. Hasil analisis dapat dilihat pada keterangan di bawah ini.

Tabel 3 Nilai total skor dari domain information

\begin{tabular}{ccccc}
\hline $\begin{array}{c}\text { Butir } \\
\text { Pernyataan }\end{array}$ & $\begin{array}{c}\text { Responde } \\
\text { n }\end{array}$ & $\begin{array}{c}\text { Jumlah } \\
\text { Skor }\end{array}$ & Mean & Kategori \\
\hline PER-A & 10 & 46 & 4.6 & Sangat Baik \\
PER-B & 10 & 42 & 4.3 & Sangat Baik \\
PER-C & 10 & 41 & 4.1 & Baik \\
\hline
\end{tabular}


120 | Dwiyantoro: Analisis dan Evaluasi Penerapan...

\begin{tabular}{ccccc}
\hline PER-D & 10 & 43 & 4.3 & Sangat Baik \\
Total & 40 & 172 & 4.3 & Sangat Baik \\
\hline
\end{tabular}

Sumber Data : diolah tahun 2018

Berdasarkan analisis yang dilakukan dengan domain information yang dilakukan pada sistem informasi smart library menunjukan nilai rata-rata mean 4,3 dengan kategori sangat baik.hal tersebut tentunya memberikan dampak positif tentang informasi yang ada pada sistem informasi smart library.

Hasil domain information di atas sesuai dengan pernyataan yang dinyatakan oleh Diana \& Andhyka, (2018) Bahwa sistem harus menyediakan informasi terformat yang tepat waktu, saling terkait, akurat dan berguna bagi pengguna dan manajer.

3. Hasil Dan Analisis Domain Economics

Pada domain Economics terdapat dua pernyataan yang digunakan untuk menganalisis Economics pada sistem smart library. Hasil analisis dapat dilihat pada keterangan di bawah ini.

Tabel 4 Nilai Total Skor Dari Domain Economics

\begin{tabular}{ccccc}
\hline $\begin{array}{c}\text { Butir } \\
\text { Pernyataan }\end{array}$ & Responden & $\begin{array}{c}\text { Jumlah } \\
\text { Skor }\end{array}$ & Mean & Kategori \\
\cline { 1 - 3 } PER-A & 10 & 29 & 2.9 & Cukup Baik \\
PER-B & 10 & 50 & 5.0 & Sangat Baik \\
Total & 20 & 79 & 3.95 & Baik \\
\hline
\end{tabular}

Sumber Data : diolah tahun 2018

Berdasarkan analisis yang dilakukan pada domain economics menunjukan nilai rata-rata Mean 3,95 dengan kategori baik, hal tersebut tentunya memberikan dampak positif pada segi ecomomic sistem informasi smart library.

Hasil domain economics di atas sesuai dengan pernyataan yang dinyatakan oleh Supriyatna, (2015) Sistem menawarkan tingkat dan kapasistas pelayanan yang memadai untuk mengurangi biaya atau meningkatkan keuntungkan.

Berdasarkan wawancara yang dilakukan dengan kepala staf amikom resource center mengatakan bahwa dalam pembuatan sistem informasi smart library amikom Resource Centre tidak mengeluarkan biaya karena sistem ini di buat oleh 
lembaga induknya. Sehingga jika di tinjau dari segi ekonomin tentunya sangat memberikan dampak positif.

4. Hasil Dan Analisis Domain Control

Pada domain Control terdapat dua pernyataan yang digunakan untuk menganalisis Control pada sistem smart library. Hasil analisis dapat dilihat pada keterangan di bawah ini.

Tabel 5 Nilai Total Skor Dari Domain Control

\begin{tabular}{ccccc}
\hline $\begin{array}{c}\text { Butir } \\
\text { Pernyataan }\end{array}$ & Responden & $\begin{array}{c}\text { Jumlah } \\
\text { Skor }\end{array}$ & Mean & Kategori \\
\hline PER-A & 10 & 50 & 5.0 & Sangat Baik \\
PER-B & 10 & 50 & 5.0 & Sangat Baik \\
Total & 20 & 100 & 5.0 & Sangat Baik \\
\hline
\end{tabular}

Sumber Data : diolah tahun 2018

Berdasarkan analisis yang dilakukan pada domain control menunjukan hasil rata-rata mean 5.0 dengan kategori sangat baik, tentunya hal tersebut memberikan dampak positif pada keamanan dan control sistem informasi smart library. Dengan begitu akan sulit bagi pengguna luar yang tidak memiliki hak akses tidak akan dapat membuka program ini.

Hasil domain control di atas sesuai dengan pernyataan yang dinyatakan oleh Supriyatna, (2015) sistem menawarkan kontrol yang memadai untuk mengatasi penipuan dan penggelapan dan untuk menjamin keakuratan dan keamanan data dan informasi.

5. Hasil Dan Analisis Domain Eficiency

Pada domain Eficiency terdapat dua pernyataan yang digunakan untuk menganalisis Eficiency pada sistem smart library. Hasil analisis dapat dilihat pada keterangan di bawah ini.

Tabel 6 Nilai Total Skor Dari Domain Efficiency

\begin{tabular}{ccccc}
\hline $\begin{array}{c}\text { Butir } \\
\text { Pernyataan }\end{array}$ & Responden & $\begin{array}{c}\text { Jumlah } \\
\text { Skor }\end{array}$ & Mean & Kategori \\
\hline PER-A & 10 & 50 & 5.0 & Sangat Baik \\
PER-B & 10 & 41 & 4.1 & Baik \\
Total & 20 & 91 & 4.55 & Sangat Baik \\
\hline
\end{tabular}


Sumber Data : diolah tahun 2018

Berdasarkan analisis data yang dilakukan pada domain efficiency menunjukan bahwa nilai rata-rata mean 4,55 dengan kategori sangat baik. Hal tersebut tentunya memberikan dampak positif terhadap eficiency yang di tawarkan oleh sistem informasi smart library.

Hasil domain efficiency diatas sesuai dengan pernyataan yang dinyatakan oleh Whitten \& Dkk, (2005) Sistem memaksimalkan sumber yang tersedia termasuk orang, waktu, aliran form, serta meminimalka penundaan proses.

6. Hasil Dan Analisis Domain Service

Pada domain Service terdapat tiga pernyataan yang digunakan untuk menganalisis Service pada sistem smart library. Hasil analisis dapat dilihat pada keterangan di bawah ini.

Tabel 7 Nilai Total Skor Dari Domain Service

\begin{tabular}{ccccc}
\hline Butir Pernyataan & Responden & Jumlah Skor & Mean & Kategori \\
\hline PER-A & 10 & 43 & 4.3 & Cukup Baik \\
PER-B & 10 & 42 & 4.2 & Baik \\
PER-C & 10 & 48 & 4.8 & Sangat Baik \\
Total & 30 & 133 & 4.43 & Sangat Baik \\
& & & & \\
\hline
\end{tabular}

Sumber Data : diolah tahun 2018

Berdasarkan analisis yang dilakuakan dengan domain service menunjukan hasil rata-rata Mean 4,43 dengan kategori sangat baik, tentunya hal tersebut berdapmpak positif terhadap kualitas service yang dimiliki pada sistem informasi smart library.

Hasil domain service di atas sesuai dengan pernyataan yang dinyatakan Diana \& Andhyka, (2018) oleh sistem menyediakan layanan yang diiginkan dan andal pada siapa saja, dan bersifat flaksibel dan dapat dikembangkan.

\section{KESIMPULAN}

Berdasarkan hasil wawancara mengenai analisis dari segi tampilan dan fitur-fitur yang ada pada smart library menunjukan bahwa smart 
library mudah di gunakan baik manual menggunakan keybord maupun menggunakan menu Pada icont. Tampilan yang ada pada smart library terbilang simpel, Hasil analisis yang dilakukan pada sistem informasi smart library menggunakan metode pendekatan Pieces Framework menunjukan bahwa pada domain peformance hasil rata-rata mean 4,4 dengan kategori sangat baik, pada domain information hasil rata-rata mean 4,3 kategori sangat baik, pada domain ekomoni hasil rata-rata mean 3,95 dengan kategori baik, pada domain kontrol hasil rata-rata mean 5,0 dengan kategori sangat baik, pada domain efisiency hasil ratarata mean 4,55 dengan kategori sangat baik, pada domain service menunjukan nilai rata-rata mean 4,43 dengan kategori sangat baik. Dengan demikian dapat disimpulkan bahwa penerapan sistem smart library yang ada di perpustakaan dinyatakan sudah baik jika dilihat dari Analisis Pieces dan sudah cukup efektif dan efisien dalam penggunaannya.

\section{DAFTAR RUJUKAN}

Agus Suharto. (2018). Analisa Evaluasi Sistem Informasi Manajemen Administrasi Akademik Dengan Metode Pieces Studi Kasus Pada Stmik Eresha. Jurnal Teknologi Informasi, Vol.8(N0 02), 37-46.

Arikunto, \& Suharsimi. (2014). Prosedur Penelitian: Suatu Pendekatan Praktik. Jakarta: Renika Cipta.

Bilson, S. (2008). Panduan riset perilaku konsumen. Jakarta: Gramedia.

Dermawan, D. (2013). Metode penelitian kuantitatif. Bandung: remaja rosdakarya.

Dewi, A. R., \& Nurjamiyah. (2018). Analisis Sistem Informasi Pengolahan Data Nilai Mahasiswa Menggunakan PIECES pada Prodi Sistem Informasi. 5341(October), 37-46.

Dewi, R. S., Marchada Rizky, R., \& Rifai, A. (2016). Analisa Pieces Penerapan Digital Monitoring Informasi Penyewaan Ruko Pasar 8 Pada Pt. Alam Sutera Realty, Tbk. Seminar Nasional Teknologi Informasi Dan Komunikasi, 644-648. Yogyakarta: SENTIKA.

Diana, K. R., \& Andhyka, K. W. (2018). Analisis Tingakt Kepuasan dan Tingkat Kepentingan Penerapan Sistem Informasi Universitas Muhammadiyah Malang. 2, 17-24.

Fatah, H. Al. (2008). Analisis dan perancangan sistem informasi. Yogyakarta: Andi Offset. 
124 | Dwiyantoro: Analisis dan Evaluasi Penerapan...

Nani Agustina. (2018). Evaluasi Penggunaan Sistem Informasi ERP Dengan Metode Pieces Framework. Jurnal Informatika, vol.5(no 2), 278-286.

Sugiyono. (2018). Metode Penelitian Kuantitatif, Kualitatif, dan R\&D (Ed. 28). Bandung: Alfabeta.

Supriyanto, W. (2009). Teknologi Informasi Perpustakaan. Yogyakarta: Kaanisun.

Supriyatna, A. (2015). Analisis dan Evaluasi Kepuasan Pengguna Sistem Informasi Perpustakaan dengan Menggunakan Pieces Framework. Jurnal Pilar Mandiri, ANALISIS D(No 1), 43-52.

Wahyono, T. (2005). Sistem Informasi; Konsep Dasar, Analisis Desain Dan Implementasi,. Yogyakarta: Grah Ilmu.

Whitten, J. L., \& Dkk. (2005). Sistems Analysis And Desingn Method (Ed.6). Yogyakarta: McGraw Hill and Andi. 